\title{
Antimicrobial Activity of Ten Extractives from Toba, North Sumatra and Mt. Merapi National Park Regions, Indonesia
}

\author{
Maya Ismayati", Deni Zulfiana, Setiawan Khoirul Himmi, Didi Tarmadi, Dita Meisyara, Apriwi Zulfitri, \\ Titik Kartika \\ Research Center for Biomaterials, Indonesian Institute of Sciences (LIPI). Jl. Raya Bogor Km. 46 Cibinong, Bogor, 16911, Jawa \\ Barat, Indonesia \\ *Corresponding author. E-mail address: maya_ismayati@biomaterial.lipi.go.id
}

\section{ARTICLE HISTORY:}

Received: 7 October 2020

Peer review completed: 5 January 2021 Received in revised form: 8 January 2021 Accepted: 11 January 2021

\section{KEYWORDS:}

Antimicrobial plants Indigenous knowledge Toba-North Sumatra Mt. Merapi
C 2021 The Author(s). Published by Department of Forestry, Faculty of Agriculture, University of Lampung in collaboration with Indonesia Network for Agroforestry Education (INAFE).

This is an open access article under the CC BY-NC license:

https://creativecommons.org/licenses/by$\mathrm{nc} / 4.0 /$

\begin{abstract}
Investigating beneficial chemical compounds of plant extracts is one of the ways to prevent biodiversity loss. This study evaluated the antimicrobial activity of indigenous plant extracts from Toba, North Sumatra, and Mt. Merapi National Park regions against Escherichia coli, Bacillus subtilis, Salmonella typhi, Staphylococcus aureus, Candida albicans, and Candida tropicalis by calculating the zone of microbial growth inhibition. Among the plant extracts, T5 that identified as Toona sinensis showed the highest microbial inhibition to the growth of C. albicans, B. subtilis, S. typhi, and $E$. coli with the diameter growth of approximately $2.00,1.80,1.33$, and $1.33 \mathrm{~cm}$, respectively. Based on those results, T. sinensis was then subsequently fractionated using n-hexane, ethyl acetate, and methanol, respectively. The resulted fractions also were evaluated for antimicrobial bioassay. All fractions have shown activity in inhibiting the growth of the microbes at $1 \%$ concentration. However, each fraction showed growth inhibition against certain microbes. The n-hexane fraction showed the greatest inhibitory activity for E. coli and S. typhi; ethyl acetate fraction for $B$. subtilis and C. albicans; and methanol fraction for E. coli and S. typhi. The results revealed that $T$. sinensis plant extract has great potential as an antimicrobial agent. Further investigation is needed to observe the mode of antimicrobial action of fractionated crude extracts of $T$. Sinensis. The exploring potency of Indonesian biodiversity opened up a new way for the utilization of plants for economic development and conservation.
\end{abstract}

\section{Introduction}

Forest is vital for life because it serves as the habitat of the vast diversity of organisms. The biodiversity of forests is also economically important for humans, mostly for wood products such as timber, pulp, paper, and rubber. In addition, forest plant extracts have hidden medicinal effects that have not been well explored. However, in recent years, biodiversity loss is threatening forest areas because of climate change and global warming. Global warming affects evapotranspiration in the dry area leads to severe drought (Trenberth et al. 2014). Forest is prone to fire when drought is occurred, causing damage to seedlings, sprouts, young and old trees. The recovery and rehabilitation process will be difficult, resulting in biodiversity loss (Nasi et al. 2002). 
Exploring forest plants and investigating the benefit of chemical compounds of plant extracts is one of the ways to prevent biodiversity loss. Plant extracts are reported to have medicinal effects such as antioxidant (Attanayake et al. 2016), antibacterial (Ogbole et al. 2018), antifungal (Giordani et al. 2020), and anticancer (Sammar et al. 2019). It also has been used as therapeutic drugs for degenerative diseases such as diabetes (Deo et al. 2016) and cardiovascular (Qadir et al. 2018). Advanced research in the pharmaceutical industry shifts people's perspectives on medicinal plants from unregulated traditional usage to phytopharmaceutical which is qualitatively and quantitatively standardized (Bhatt 2016). This leads to increasing demands for plant-based medicine.

Knowledge of the benefit of ethnobotanical plants (as medicinal, antimicrobial, and bioinsecticide) is expected to increase people's awareness to conserve the forests. People will begin to appreciate forests by using them as medicinal plant sources and will implement them as local culture. Local culture will encourage the creation of a legal system to prevent anything that damages the forests, such as wildfire or human activities. Therefore, it will help in avoiding biodiversity loss.

In line with the Indonesia Biodiversity Strategy and Action Plan (IBSAP) program, the exploration of plant extract that has the potential as bio-insecticides based on the local wisdom of the community have been conducted in Toba-North Sumatra (Meisyara et al. 2019) and Turgo Forest Area, Mt. Merapi National Park, Java. In this study, the collected plants in the previous project were screened to discover another potential activity as an antimicrobial agent.

\section{Materials and Methods}

In line with the Indonesia Biodiversity Strategy and Action Plan (IBSAP) program, the exploration of plant extract that has the potential as bio-insecticides based on the local wisdom of the community have been conducted in Toba-North Sumatra (Meisyara et al. 2019) and Turgo Forest Area, Mt. Merapi National Park, Java (Ismayati et al. 2019) (Fig. 1). About 4 plant samples were collected from Mt. Merapi, and 6 plant samples were collected from the Toba regions (Samosir Botanical Garden and Eden 100 Park Area). All samples were extracted by maceration process to get methanol crude extract, and followed by a phytochemical test (Meisyara et al. 2019).
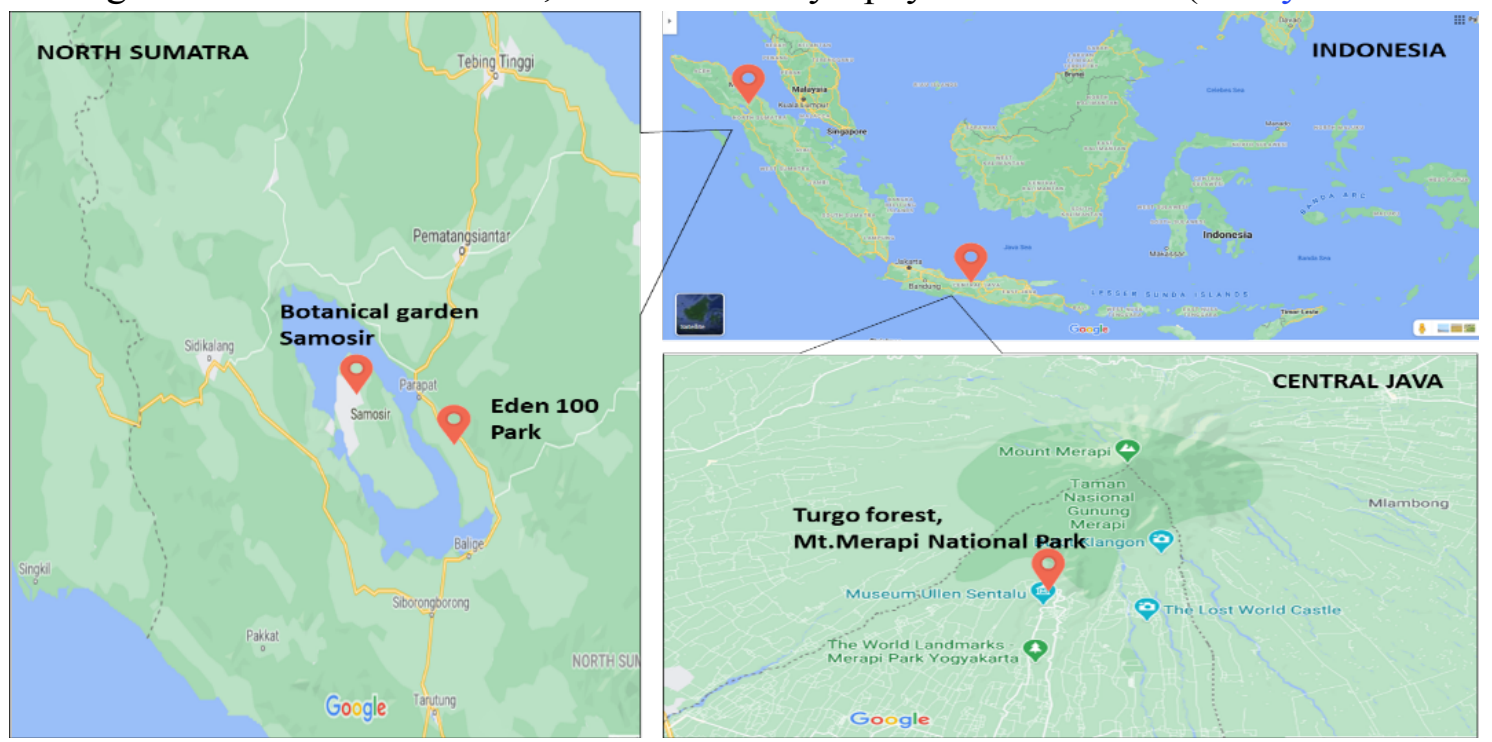

Fig. 1. Sampling location in Toba, North Sumatra and Mt. Merapi National Park, Java, Indonesia (Source: www.maps.google.com) 
Antimicrobial bioassay for 10 plant extracts was carried out against 6 microbial pathogens, including Escherichia coli, Bacillus subtilis, Salmonella typhi, Staphylococcus aureus (bacteria), and Candida albicans, Candida tropicalis (yeast) using the disc diffusion method. Microbial pathogenic agar plates were made by mixing $1 \%$ of each bacterial and yeast inoculum with a density of about $10^{-7} \mathrm{cfu} / \mathrm{ml}$, respectively, with $20 \mathrm{ml}$ molten agar media (nutrient agar for bacteria and potato dextrose agar for yeast) and then pour it into petri dishes. $50 \mu 1$ plant extract $(10,000$ ppm in methanol) was injected onto a paper disc $(0.8 \mathrm{~cm})$ and placed on the microbial inoculated agar. Methanol was used as a control. The plates were then incubated at $25^{\circ} \mathrm{C}$ for $48 \mathrm{~h}$. Observation of microbial inhibition zone diameter (clear zone formation) was carried out at 24 and $48 \mathrm{~h}$.

The plant extract with the highest antimicrobial activity was fractioned by the gradient polarity of the solvent. Ethyl acetate was chosen as the semi-polar solvent, and $n$-hexane was used for nonpolar solvent. Each extract with concentration of $0.1 \% ; 0.2 \% ; 0.4 \% ; 0.6 \% ; 0.8 \%$ and $1.0 \%$ $\mathrm{w} / \mathrm{v}$ were subjected into the same antimicrobial test following the aforementioned methods.

The effects of plant extractives treatment on the inhibition zone of pathogen microbial were statistically determined by analysis of variance (ANOVA), and samples showing significant differences were analyzed using Duncan's post hoc test. All analyses were performed using IBM SPSS version 2.2.

\section{Results and Discussion}

Biodiversity plays a significant role in the development of the country. In line with the objectives of the 2015-2020 IBSAP program, the exploration of biodiversity in the archipelago has a role in increasing people's productivity and national competitiveness, and economic independence. The results of this exploration are expected to be used as material for analysis in the management and utilization of sustainable biodiversity to achieve development targets.

From this exploration activity, 6 plant extracts from the Toba area and 4 plant extracts from the Merapi area were collected. The plant extracts were identified and reported in previous studies (Ismayati et al. 2019; Meisyara et al. 2018). They are leaves and barks of kina (Cinchona pubescens Vahl), leaf of kamadoh (Dendrocnide stimulans (L.f.) Chew), and keremi (Homalanthus populneus (Geiseler) Pax); leaf of simar pahit-pahit (Tithonia diversifolia (Hemsl.) A. Gray), imar huting-huting (Chromolaena odorata (L.) R.M. King \& H. Rob), pirdot (Saurauia bracteosa DC.), Ingul (Toona sinensis), haurese (Azadirachta indica A. Juss), and bark of sikkam (Turpinia sphaerocarpa Hassk).

The chemical content analysis of plant extracts has been carried out for the phytochemical test (Table 1). Each plant extract showed various content of phytochemicals, although none of the extracts contain triterpenoid. Variation in pathogen growth inhibition may be influenced by differences in the chemical content of the plant extract samples.

The results of the antimicrobial activity of plant extracts are shown in Fig. 2. The ANOVA indicated that all plant extracts showed antimicrobial activity against bacterial pathogens tested with various potencies. T. sinensis (T5) extract at 10,000 ppm was found to be the most effective in suppressing all bacterial and yeast pathogenic growth tested in vitro. In contrast, extract of keremi (Homalanthus populneus (Geiseler) Pax) exhibited antibacterial activity only against $S$. aureus. Other plant extracts were variously effective against bacterial pathogen E. coli, B. subtilis, and $S$. aureus but showed no inhibitory effect on the growth of $S$. typhi and yeast pathogens. The significant differences $(p=0.001)$ in the mean of growth inhibition zone for those three pathogens 
were only observed at the treatment of T5. The clear zone of S. typhi, C. albicans, and C. tropicalis after treated with 10,000 ppm T5 were $1.90 \mathrm{~cm} ; 1.20 \mathrm{~cm}$; and $0.40 \mathrm{~cm}$, respectively.

Table 1. The phytochemical test result of plant extractives collected

\begin{tabular}{|c|c|c|c|c|c|c|c|c|}
\hline \multirow{2}{*}{ Code } & \multirow{2}{*}{ Location } & \multirow{2}{*}{$\begin{array}{l}\text { Local name } \\
\text { Yield (\%) }\end{array}$} & \multicolumn{6}{|c|}{ Phytochemical test result } \\
\hline & & & Alkaloid & Flavonoid & Steroid & Triterpenoid & Saponin & Tannin \\
\hline B1 & $\begin{array}{l}\text { Mt. Merapi } \\
\text { National }\end{array}$ & $\begin{array}{l}\text { Kina (Cinchona } \\
\text { pubescens Vahl) }\end{array}$ & + & - & - & - & + & - \\
\hline B2 & $\begin{array}{l}\text { Park, Java } \\
\text { (Ismayati et }\end{array}$ & $\begin{array}{l}\text { Kina (Cinchona } \\
\text { pubescens Vahl) }\end{array}$ & + & + & - & - & + & + \\
\hline B3 & al. 2019) & $\begin{array}{l}\text { Kamadoh } \\
\text { (Dendrocnide } \\
\text { stimulans (L.f.) Chew) }\end{array}$ & - & - & - & - & + & - \\
\hline B4 & & $\begin{array}{l}\text { Keremi (Homalanthus } \\
\text { populneus (Geiseler) } \\
\text { Pax) }\end{array}$ & - & - & - & - & - & + \\
\hline $\mathrm{T} 1$ & $\begin{array}{l}\text { Toba region, } \\
\text { Sumatera } \\
\text { (Meisyara et }\end{array}$ & $\begin{array}{l}\text { Simar pahit-pahit } \\
\text { (Tithonia diversifolia } \\
\text { (Hemsl.) A. Gray) }\end{array}$ & - & - & + & - & - & - \\
\hline $\mathrm{T} 2$ & al. 2019) & $\begin{array}{l}\text { Simar huting-huting } \\
\text { (Chromolaena } \\
\text { odorata (L.) R.M. } \\
\text { King \& H. Rob) }\end{array}$ & - & + & - & - & - & + \\
\hline $\mathrm{T} 3$ & & $\begin{array}{l}\text { Pirdot (Saurauia } \\
\text { bracteosa DC.) }\end{array}$ & - & - & + & - & - & + \\
\hline $\mathrm{T} 4$ & & $\begin{array}{l}\text { Sikkam (Turpinia } \\
\text { sphaerocarpa } \text { Hassk) }\end{array}$ & - & + & - & - & - & + \\
\hline T5 & & Ingul (Toona sinensis) & - & - & + & - & - & + \\
\hline T6 & & $\begin{array}{l}\text { Hauresse } \\
\text { (Azadirachta indica } \\
\text { A. Juss) }\end{array}$ & - & + & + & - & + & + \\
\hline
\end{tabular}

T. sinensis showed the highest inhibitory against all pathogens tested above and the result is in accordance with the activity of $T$. sinensis as antitumor, hypoglycemic, antioxidant, antiinflammatory, antibacterial, and antiviral, as reported by Peng et al. (2019). According to phytochemical test, $T$. sinensis has steroid and tannin that might act as active compound against the pathogen. Similar results showed that $T$. sinensis activity against $S$. aureus was due to the presence of sesquiterpenes $(84.64 \%)$, including copaene $(8.27 \%), \beta$-caryophyllene $(10.16 \%)$, caryophyllene (13.18\%), and $\beta$-eudesmene (5.06\%) (Wu et al. 2014). The difference in terpenoid compounds that did not appear in the chemical analysis may be correlated to the different location growth and age of the plant (Ismayati et al. 2017).

Escherichia coli

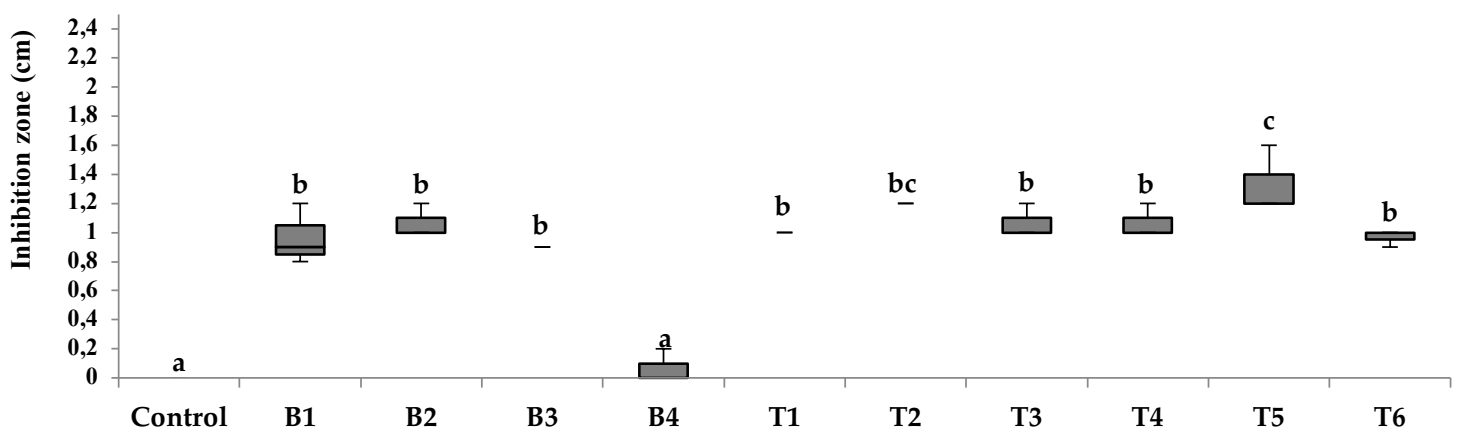


Bacillus subtilis

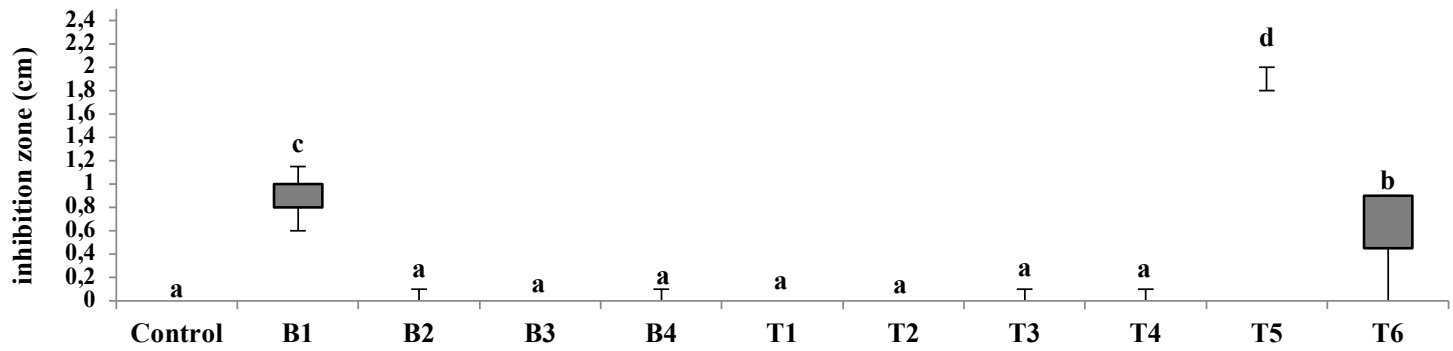

Salmonella typhi

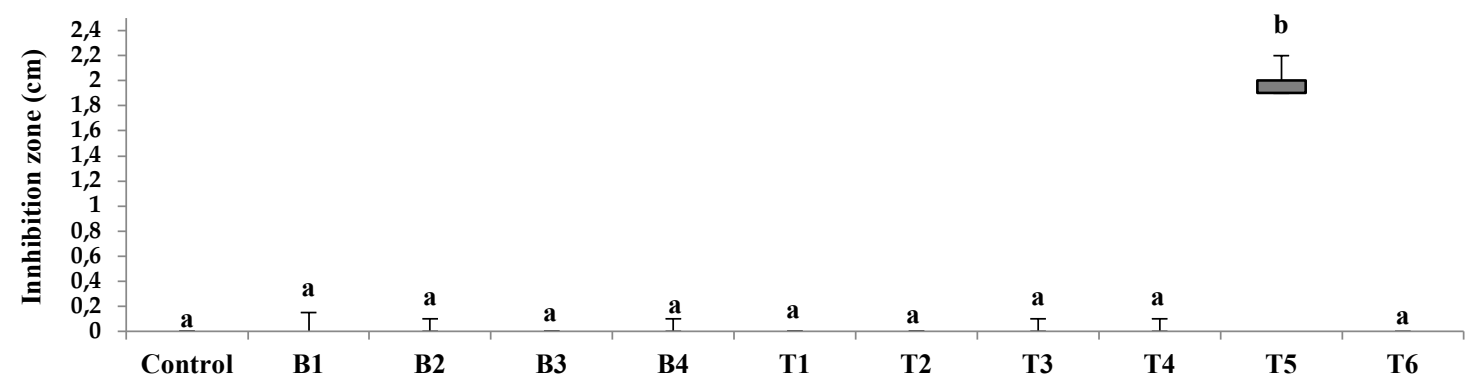

Staphylococcus aureus

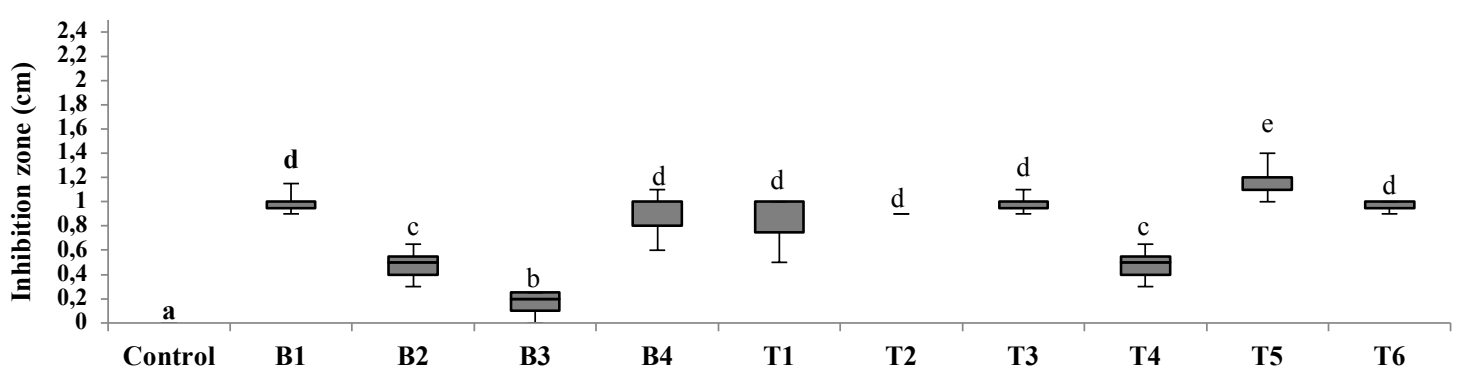

Candida albicans

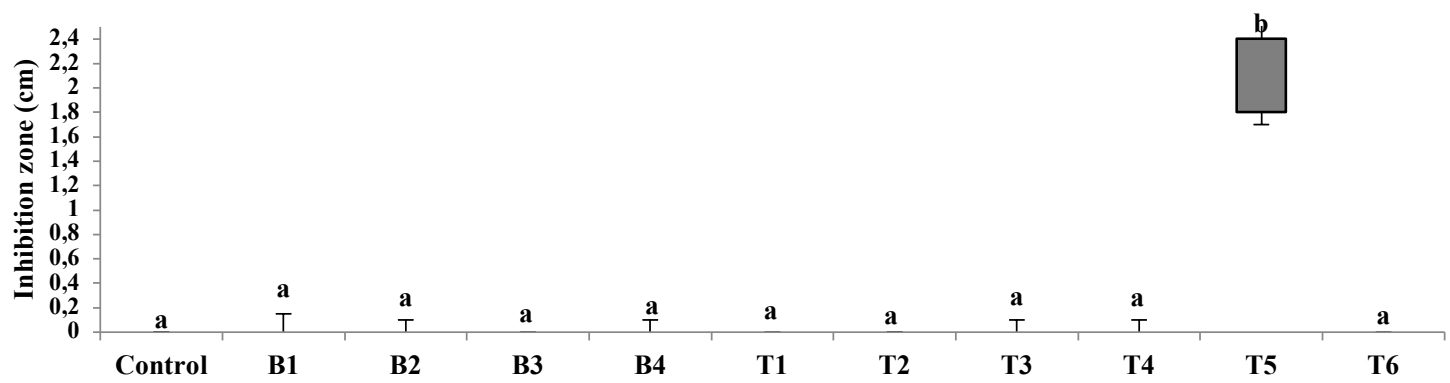

Candida tropicalis

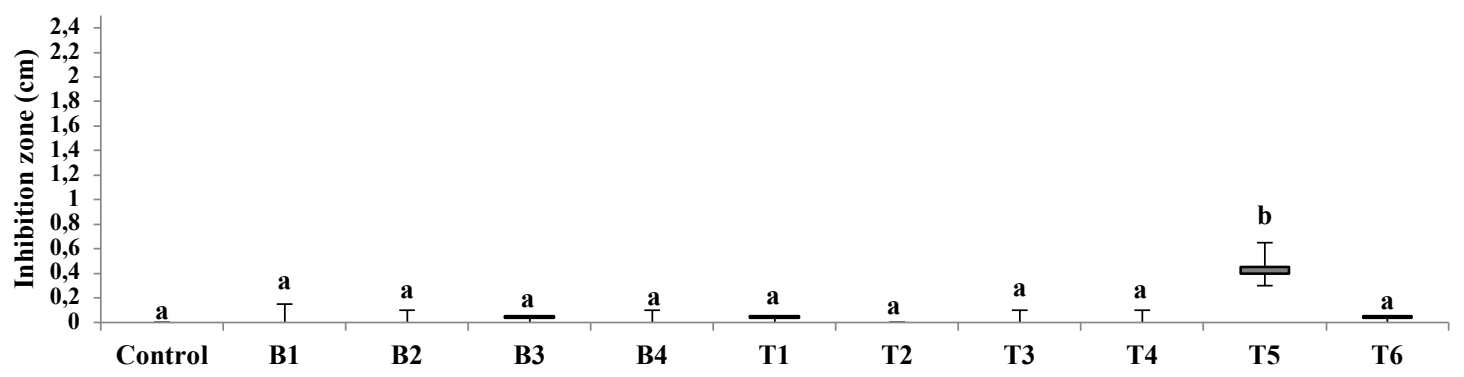

Fig. 2. Box plot of inhibition zone of bacteria and yeast in antimicrobial bioassay in some crude extractives, $1 \%(\mathrm{w} / \mathrm{v})$ (Legends: Treatments with the same letters in the same graphic are not statistically different at $p<0.05$, as determined by Duncan's test; sample codes are referred to

Table 1). 
Although in this study, other extracts did not achieve antimicrobial activity as good as $T$. sinensis, previous studies reported that some of the extracts also have considerable antimicrobial activity. Tithonia diversifolia showed great antimicrobial activity on a particular microbial pathogen as Pseudomonas aeruginosa (Oso and Ogunnusi 2017). On the other hand, Azadirachta indica extract showed antimicrobial activity against Gram-positive bacteria and favorable for foodborne pathogens and spoilage organisms (Mahfuzul Hoque et al. 2007).

The antimicrobial activity of plants was believed originally from their secondary metabolites. The secondary metabolites of nine collected plants were analyzed with a phytochemical test and the result is showed in Table 1. Plant-alkaloids, such as sanguarine, tomatidine, reserpine, piperine, and cinchona alkaloids, are reported to have high antimicrobial activity against a broad range of bacteria (Barbieri et al. 2017). Flavonoids have promising antimicrobial activity, such as selectively targeting bacterial cells, restricting virulence factors, and biofilm formation (Górniak et al. 2019). Steroids from two Chromolaena species (Taleb Contini et al. 2003) and Nerium oleander (Archit et al. 2014) showed activity against Gram-positive bacteria. Triterpenoids isolated from Dissotis senegambiensis and Amphiblemma monticola showed antibacterial activity against methicillin-resistant $S$. Aureus (Nzogong et al. 2018). Saponin extracts from fifteen indigenous plants from Turkey are reported effective against Escherichia coli, Pseudomonas aeruginosa, Streptococcus faecalis, Staphylococcus aureus, Candida albicans, Candida parapsilosis, Candida pseudotropicalis, and Candida stellatoidea. Tannins' mode of action against bacteria includes inhibition of extracellular microbial enzymes, deprivation of the substrates required for microbial growth, or direct action on microbial metabolism through inhibition of oxidative phosphorylation, also through iron deprivation (Scalbert 1991).

The results suggested that $T$. sinensis extract showed a strong antimicrobial effect against pathogens strains. Therefore, to further clarify the effect of extractive content of $T$. sinensis, the crude extract was fractionated into polar and nonpolar fractions using gradient solvent in polarity ( $n$-hexane, ethyl acetate, and methanol). Obtained fractions were then exposed against all pathogens. As seen in Fig. 3, the growth inhibition zone's diameter tends to increase by higher fraction concentration. On $n$-hexane fraction, the zone's diameter in all pathogen seems to similar for all concentrations. A significant difference was seen at a concentration of $0.6 \%(\mathrm{w} / \mathrm{v})$ and above, with the inhibition zone's diameter about $0.8-1.6 \mathrm{~cm}$. Meanwhile, the diameter zone shown a slightly higher than $n$-hexane, it is about $2.0 \mathrm{~cm}$. A significant difference effect was also found in phenolate content in $T$. sinensis, polar extract (n-butanol and ethyl acetate, 36.42 and $31.64 \mathrm{mg}$ ) have a higher content than nonpolar solvent (n-hexane, $10.06 \mathrm{mg}$ ) (Murningsih 2015). A strange phenomenon has occurred in the bacteria $S$. aureus and B. subtilis, where only at a concentration of $1 \%$ the addition of the extract can inhibit the growth zone. As gram-negative bacteria, both of them are protected from certain physical assaults and do not absorb foreign materials that surround them as easier as gram-positive bacteria (Segun et al. 2015). Meanwhile, the ethyl acetate fraction showed high inhibition with clear zone diameters of about $1.65 \mathrm{~cm}$ and $1.55 \mathrm{~cm}$ in C. albicans and C. tropicalis. 
E. coli

$n$-Hexane fraction

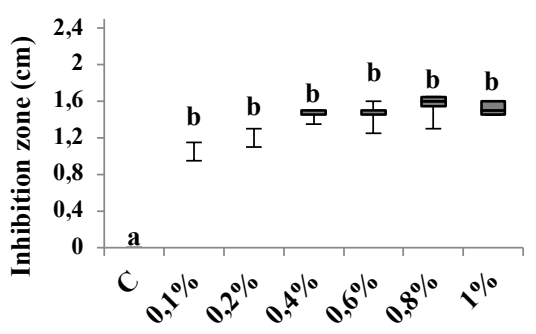

B. subtilis

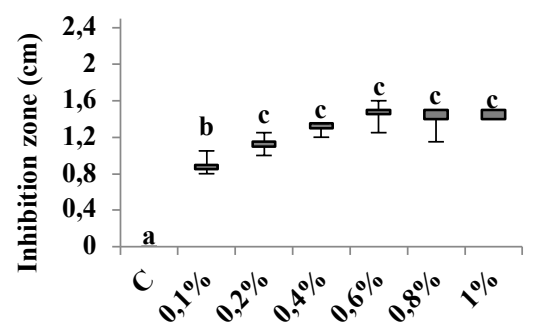

S. typhi

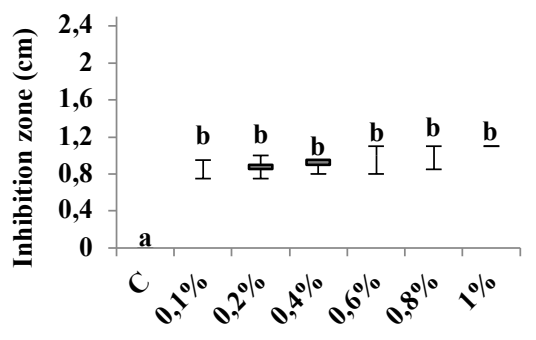

S. aureus

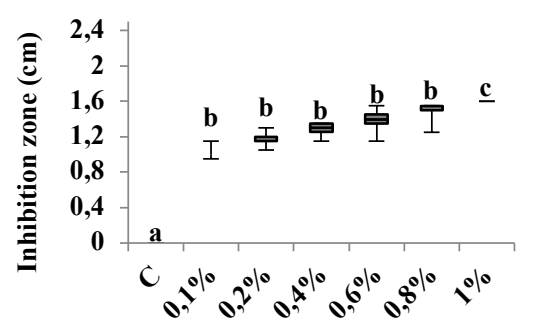

C. albicans

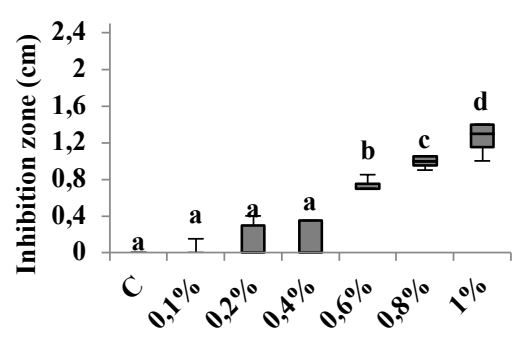

Ethyl acetate fraction

Methanol fraction
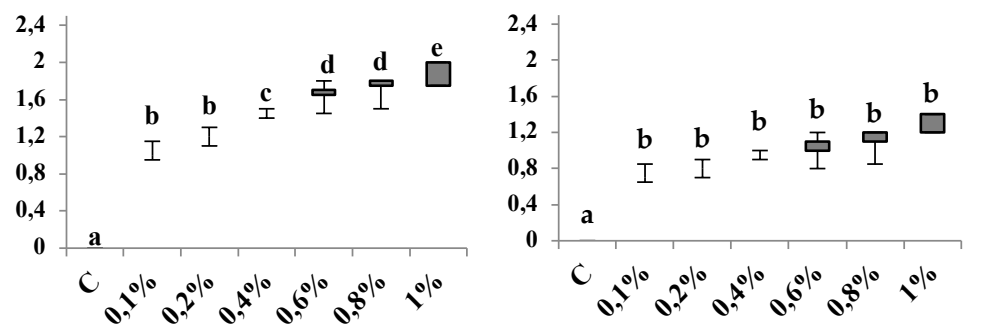

Concentration $(\%, \mathrm{w} / \mathrm{v})$
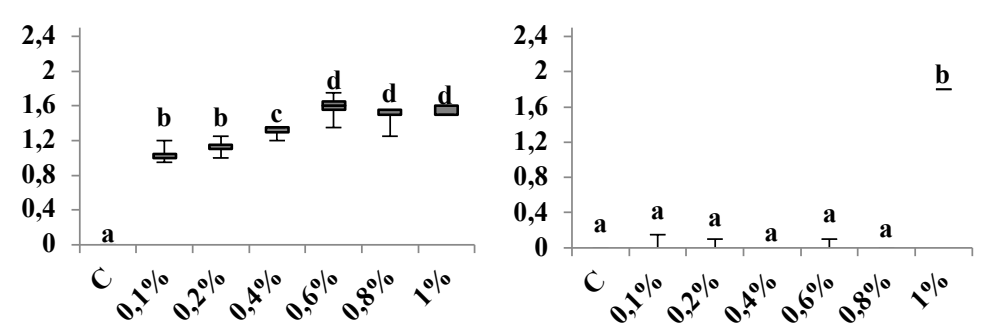

Concentration $(\%, w / v)$
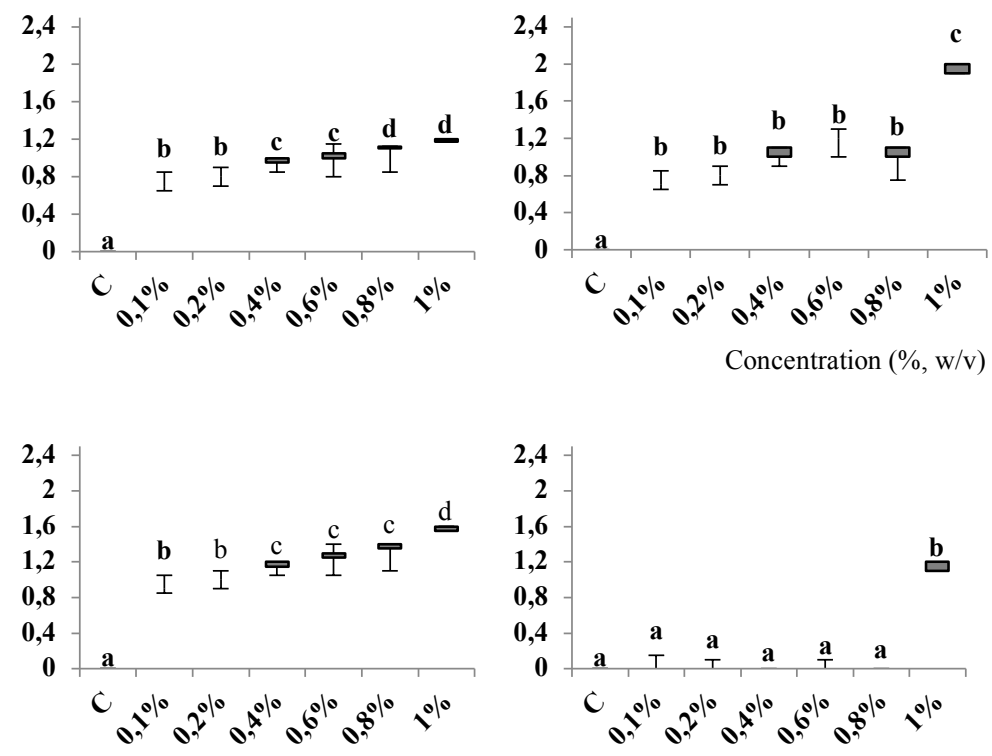

Concentration $(\%, w / v)$

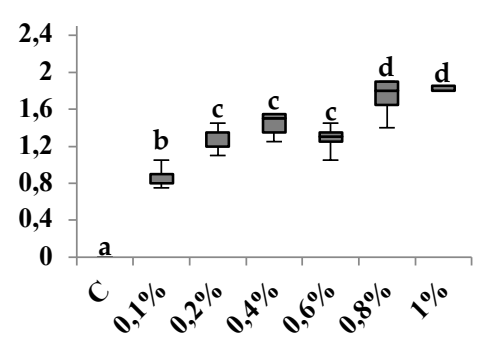

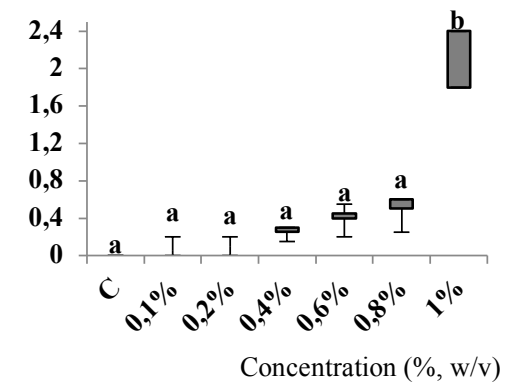




\section{C. tropicalis}
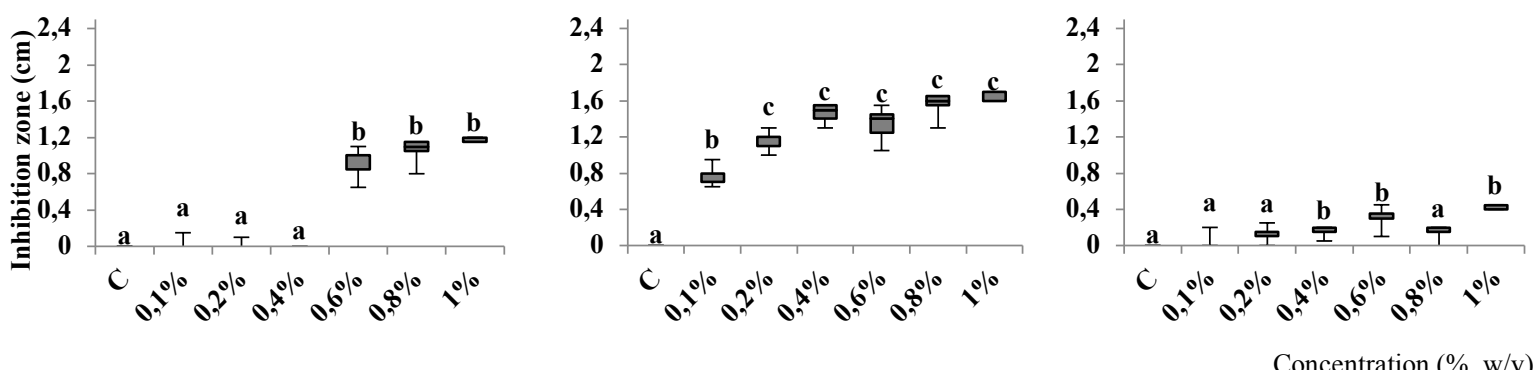

Fig. 3. Box plot of inhibition zone of bacteria and yeast in antimicrobial bioassay for $n$-hexane, ethyl acetate, and methanol fractions (Legends: Treatments with the same letters in the same graphic are not statistically different at $p<0.05$, as determined by Duncan's test; sample codes are referred to Table 1).

Further study is needed to explore the potency of antimicrobial activity related to chemical composition. The production of standardized extracts from plants is a real potential for improving local communities' economy and important information in terms of plant conservation.

\section{Conclusions}

The present study showed that all samples collected from Toba, North Sumatra, and Mt. Merapi national park have potential antimicrobial. Toona sinensis (T5) was presented as the most active in inhibiting the growth of $C$. albicans, B. subtilis, S. typhi, and E. coli, with the diameter growth about $2.00,1.80,1.33$, and $1.33 \mathrm{~cm}$, respectively. The $n$-hexane fraction shows the greatest inhibitory activity for E. coli and S. aureus; ethyl acetate fraction for E. coli, B. subtilis, and C. albicans; and methanol fraction for E. coli and $S$. typhi. Further investigation is needed to observe the mode of action onto microbial growth that caused by the chemical content of $T$. sinensis.

\section{Acknowledgments}

This research was funded by the Indonesian Biodiversity Strategy and Action Plan (IBSAP) Project -2018 . The authors would like to thank the staff of Mt. Merapi National Park for their help in the field.

\section{References}

Archit, R., Mythili, S., and Sathiavelu, A. 2014. Evaluation of Antimicrobial Efficacy of Flavonoids, Alkaloids, and Steroids of Nerium oleander Linn Against some Pathogenic Bacteria. International Journal of Drug Development and Research 6(1): 231-238.

Attanayake, A., Jayatilaka, K., and Malkanthi, B. 2016. Total Flavonoid Content, Total Antioxidant Activities, and Phytochemical Constituents of Selected Medicinal Plant Extracts used for Oxidative Stress-Related Chronic Diseases in Sri Lanka. The Journal of Medicinal Plants Studies 26(46): 26-29.

Barbieri, R., Coppo, E., Marchese, A., Daglia, M., Sobarzo-Sánchez, E., Nabavi, S.F., and Nabavi, S.M. 2017. Phytochemicals for Human Disease: An Update on plant-Derived Compounds Antibacterial Activity. Microbiological Research 196: 44-68. DOI: 


\subsection{6/j.micres.2016.12.003}

Bhatt, A. 2016. Phytopharmaceuticals: A new Drug Class Regulated in India. Perspectives in Clinical Research 7(2): 59-61. DOI: 10.4103/2229-3485.179435

Deo, P., Hewawasam, E., Karakoulakis, A., Claudie, D.J., Nelson, R., Simpson, B.S., Smith, N.M., and Semple, S.J. 2016. In vitro Inhibitory Activities of Selected Australian Medicinal Plant Extracts against Protein Glycation, Angiotensin Converting Enzyme (ACE) and Digestive Enzymes Linked to Type II Diabetes. BMC Complementary Medicine and Therapies 16(1): 435. DOI: 10.1186/s12906-016-1421-5

Giordani, C., Simonetti, G., Natsagdorj, D., Choijamts, G., Ghirga, F., Calcaterra, A., Quaglio, D., Angelis, G.D., Toniolo, C., and Pasqua, G. 2020. Antifungal Activity of Mongolian medicinal Plant Extracts. Natural Product Research 34(4): 449-455. DOI: 10.1080/14786419.2019.1610960

Górniak, I., Bartoszewski, R., and Króliczewski, J. 2019. Comprehensive Review of Antimicrobial Activities of Plant Flavonoids. Phytochemistry Reviews 18(1): 241-272. DOI: 10.1007/s11101-018-9591-z

Ismayati, M., Nakagawa-izumi, A., and Ohi, H. 2017. Structural Elucidation of Condensed Tannin from the Bark Waste of Acacia crassicarpa Plantation Wood in Indonesia. Journal of Wood Science 63(4): 350-359.

Ismayati, M., Zulfiana, D., Tarmadi, D., Lestari, A.S., Krishanti, N.P.R.A., Himmi, S.K., and Yusuf, S. 2019. Biological Control of Wood Destroying Organism Using Plant Extracts Collected from Mt. Merapi National Park, Indonesia. Biosaintifika: Journal of Biology \& Biology Education 11(3): 360-368.

Mahfuzul Hoque, M.D., Bari, M.L., Inatsu, Y., Juneja, V.K., and Kawamoto, S. 2007. Antibacterial Activity of Guava (Psidium guajava L.) and Neem (Azadirachta indica A. Juss.) Extracts Against Foodborne Pathogens and Spoilage Bacteria. Foodborne Pathogens and Disease 4(4): 481-488. DOI: 10.1089/fpd.2007.0040

Meisyara, D., Krishanti, N.P.R.A., Zulfitri, A., Lestari, A.S., Tarmadi, D., Himmi, S.K., and Ismayati, M. 2019. Biological Activity of Local Plant Extracts from Toba Region as Insecticide. IOP Conference Series: Earth and Environmental Science 374(1): 012006.

Murningsih, T. 2015. Effect of Partition Solvents on Total Phenolic Contents and Antioxidant Activities of Toona sinensis Bark Extract. Berita Biologi 14(2): 169-175.

Nasi, R., Dennis, R., Meijaard, E., Applegate, G., and Moore, P. 2002. Forest Fire and Biological Diversity. Unasylva 209: 53.

Nzogong, R.T., Ndjateu, F.S.T., Ekom, S.E., Fosso, J.A.M., Awouafack, M.D., Tene, M., Tane, P., Morita, H., Choudhary, M.I., and Tamokou, J.D. 2018. Antimicrobial and antioxidant Activities of Triterpenoid and Phenolic Derivatives from Two Cameroonian Melastomataceae Plants: Dissotis senegambiensis and Amphiblemma monticola. BMC Complement Altern Med 18(1): 159. DOI: 10.1186/s12906-018-2229-2

Ogbole, O.O., Segun, P.A., and Fasinu, P.S. 2018. Antimicrobial and Antiprotozoal Activities of Twenty-Four Nigerian Medicinal Plant Extracts. South African Journal of Botany 117:240 246. DOI: $10.1016 / j$.sajb.2018.05.028

Oso, B., and Ogunnusi, T. 2017. Antibacterial Activity of Methanolic Extracts of Euphorbia heterophylla and Tithonia diversifolia against Some Microorganisms. European Journal of Medicinal Plants 20(3): 1-8. DOI: 10.9734/ejmp/2017/28568

Peng, W., Liu, Y., Hu, M., Zhang, M., Yang, J., Liang, F., and Wu, C. 2019. Toona sinensis: A 
Comprehensive Review on Its Traditional Usages, Phytochemisty, Pharmacology and Toxicology. Revista Brasileira de Farmacognosia 29(1): 111-124.

Qadir, M.I., Manzoor, A., and Akash, M.S.H. 2018. Potential Role of Medicinal Plants for AntiAtherosclerosis Activity. Bangladesh Journal of Pharmacology 13(1): 59-66. DOI: 10.3329/bjp.v13i1.33478

Sammar, M., Abu-Farich, B., Rayan, I., Falah, M., and Rayan, A. 2019. Correlation between Cytotoxicity in cancer Cells and free Radical-Scavenging Activity: In Vitro Evaluation of 57 Medicinal and Edible Plant Extracts. Oncology Letters 18(6): 6563-6571. DOI: 10.3892/ol.2019.11054

Scalbert, A. 1991. Antimicrobial Properties of Tannins. Phytochemistry 30(12): 3875-3883. DOI: 10.1016/0031-9422(91)83426-L

Segun, A.A., Samuel, F.O., and Aminat, A.T. 2015. Assessment of Antibacterial Activity of Essential Oil Extracted from Leaves of Thaumatococcus danielli (Benn.) Benth. in light of Its Inhibitory Impact on Extracellular Protease of Shigella Dysenteriae. International Journal of Biochemistry Research and Review 5(1): 9.

Taleb Contini, S., Salvador, M., Watanabe, E., Ito, I., and Oliveira, D. 2003. Antimicrobial Activity of Flavonoids and Steroids Isolated From Two Chromolaena Species. The Brazilian Journal of Pharmaceutical Sciences 39. DOI: 10.1590/S1516-93322003000400007

Trenberth, K.E., Dai, A., van der Schrier, G., Jones, P.D., Barichivich, J., Briffa, K.R., and Sheffield, J. 2014. Global Warming and Changes in Drought. Nature Climate Change 4(1): 17-22. DOI: 10.1038/nclimate2067

Wu, J. G., Peng, W., Yi, J., Wu, Y. B., Chen, T. Q., Wong, K. H., and Wu, J. Z. 2014. Chemical Composition, Antimicrobial Activity against Staphylococcus aureus and a Pro-Apoptotic Effect in SGC-7901 of the Essential Oil from Toona sinensis (A. Juss.) Roem. Leaves. Journal of Ethnopharmacology 154(1): 198-205. DOI: 10.1016/j.jep.2014.04.002 